\title{
Analysis on Current Situation of Business English Teaching and Improvement of Curriculum System
}

\author{
Guoqing Zhang \\ No.1488, Buoshuo Road, Jingyue District, Changchun City, Jilin Province, China \\ 153266111@qq.com
}

Keywords: Practice courses; Business English teaching; Construction; Curriculum system

\begin{abstract}
In recent years, the deepening of globalization and the strengthening of relations between countries have made international trade develop unprecedentedly. Business English talents, as communication talents in international trade, play a vital role in international trade activities. At present, business English teaching in Chinese institutions has made significant progress in talent training, professional construction and core competitiveness. However, compared with the market demand and the actual needs of enterprises, there are still some deficiencies, among which the cultivation of students' practical ability is more prominent. In this paper, on the basis of the ability-oriented teaching concept, from the perspective of practice ability analysis of current business English teaching in colleges and universities, the paper aims to put forward the strategies for curriculum system construction. Many research methods, such as questionnaire and interview, are used in the paper. The paper mainly focused on the College of Sciences and Humanities of the Northeast Normal University, which is a third-level college in China, so the data collected can not represent the majorities of colleges in China. The result of the research is still of great importance. The theories of the present situation of the business English major, comprehensive ability-oriented training and the task-based teaching methods of value. The result of the research will be widely used in the improvement of the curriculum, the text book, the methods of teaching, etc. Other institution would also gain important information from it.
\end{abstract}

\section{Introduction}

The sample in the research College of Sciences and Humanities of the Northeast Normal University is a third-level university in China. It represents a large group of colleges. The average students are with relatively low-level English ability.

Business English is a major mainly focuses on the application of the English ability. It is also a combination of basic English skills and business knowledge. The teaching content and methods should be different from those of traditional English courses.

\section{Investigation on the Present Teaching Situation of Business English Major.}

A survey was conducted on the current situation of Business English teaching in the International Business School of College of Sciences and Humanities of the Northeast Normal University. The research methods of questionnaire and interview were used in the survey and the samples are the teachers and students, the graduates of Business English major. The survey aims to find out the content, teaching methods and place of the teaching of practical courses, the ways and time of the internship, the acquisition the vocational qualification. Meanwhile, the research methods of E-mail questionnaires, QQ interview and telephone communications, etc. were used to contact the enterprises to learn about the types and job, required knowledge, current capability and the graduates of Business English major. Based on the collection and analysis of the information, the practical problems of Business English teaching in the college are concluded. Due to the limitation of space, this article only discusses the results.

The author randomly interviewed 24 foreign trade employees, including supervisors, managers, front-line operators, etc., and raised six questions to be discussed: What types of jobs are the business English major doing? What is the comprehensive business performance like? What is the result of the comprehensive ability evaluation? What the is degree of satisfaction of the graduates? 
What is the degree of matching of the the graduates ability and the level of enterprises. Based on the results of the interview, the demand of market in talents are analyzed.

The result shows that more than $60 \%$ of business English professional talents work at the grassroots level, which means that in the English teaching process, more attention should be paid to comprehensive foreign trade practices, including correspondence and telecommunications, cost calculation, verification and cancellation, tax rebate, etc. Business English professionals have prominent defects in computer application and practical ability, and their dissatisfaction degree exceeds $50 \%$. More than half of interviewees believe that pre-job internship is necessary for business English professionals, and none believe that this kind training is not necessary.In conclusion, the talent requirement of current enterprises far more exceeds the present ability of business English majors. In order to solve this problem, it is urgent to improve the curriculum system of professional practice.

100 copies of questionnaires are randomly sent out to the teachers, students and graduates of business English majors of College of Sciences and Humanities of the Northeast Normal Universities and 82 copies are effective. The results are as follows:

1. Whether business English teaching can meet the needs of students' ability development?

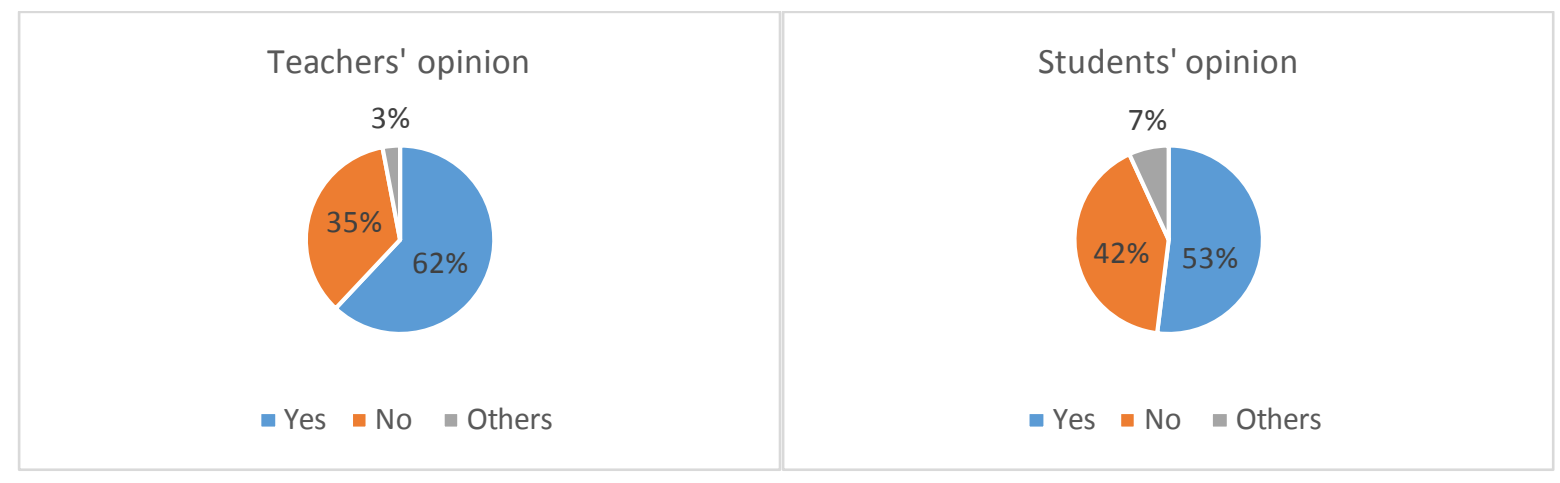

Figure 1. Finite The result of the first question in the questionnaire

In the questionnaire, the question of whether teaching can meet the needs of students' ability development, more than $60 \%$ of the teachers and more than $50 \%$ of the students held positive attitudes. However, based on the results of the opinions of enterprises mentioned above, there exists a big gap between the teaching and the actual market demand.

2. Does teaching enable students to obtain the expected practical ability of business English? (Whether the students can obtain certain certifications necessary after learning the courses provided by business English?)

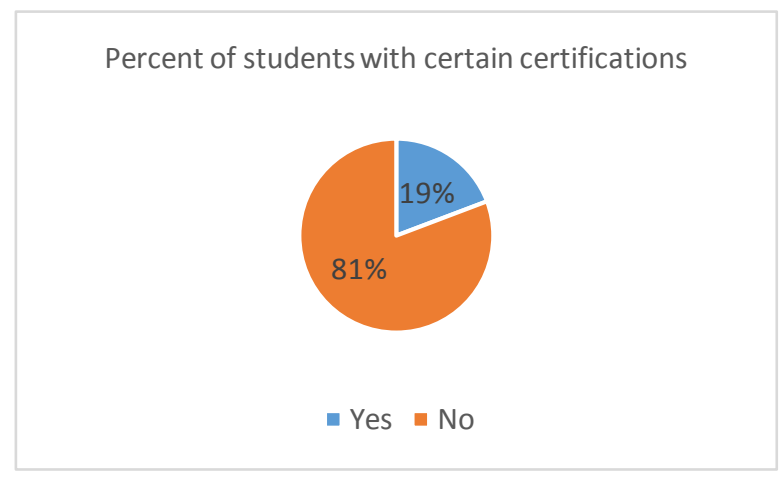

Figure 2. Finite The result of the second question in the questionnaire

Only less than $20 \%$ of the students said they had obtained relevant certificates (National Certificate of International Business English, Cambridge Business English Certificate level 2, Certificate of Documentary Evidence,etc.), which means most of the students can not meet the international and national requirement for business English majors. 
3. Are teaching methods in practical courses different from those in theoretical classes?

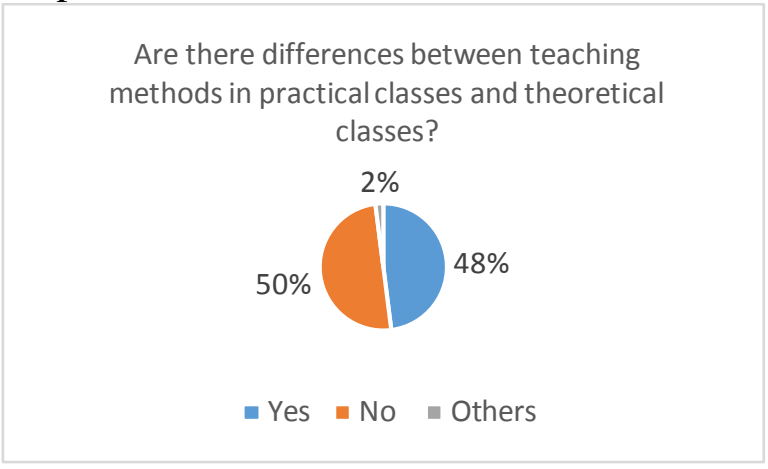

Figure 3. Finite The result of the third question in the questionnaire

About $50 \%$ of teachers and students agree that there is no significant difference between the teaching methods of practical courses and that of theoretical courses. It can be concluded that there are defects in the curriculum of practical teaching system. Currently, there are obvious defects in the practical teaching system in business English in colleges, such as the unreasonable setting of teaching objectives, the insufficient attention to the students' practical operation ability and improper teaching methods.

4. Where do the students have practical classes?

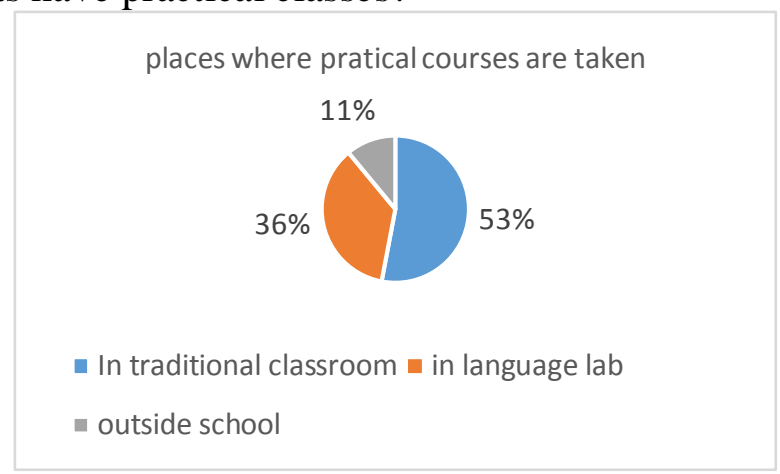

Figure 4. Finite The result of the fourth question in the questionnaire

As illustrated in the pie chart,more than half of the business English practice teaching courses are conducted in ordinary classrooms. Only about one tenth in outside school, which is obviously in shortage.

5. Teaching in the language laboratory is mostly related to language operation, and less related to interpretation skills and business secretary. What are practiced in the language lab?

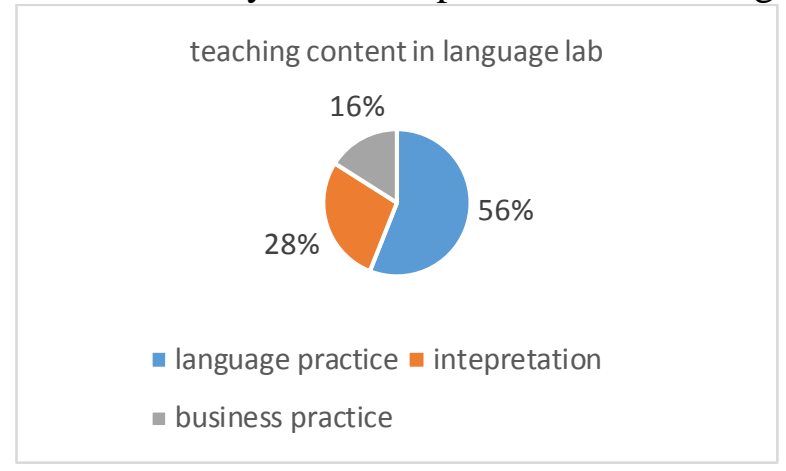

Figure 5. Finite The result of the fifth question in the questionnaire

It can be seen that teaching in the language laboratory is mostly related to language operation, and less related to interpretation skills and business-related practice, which are primarily task-based.

6. Could the intensive practical courses satisfy the need? 


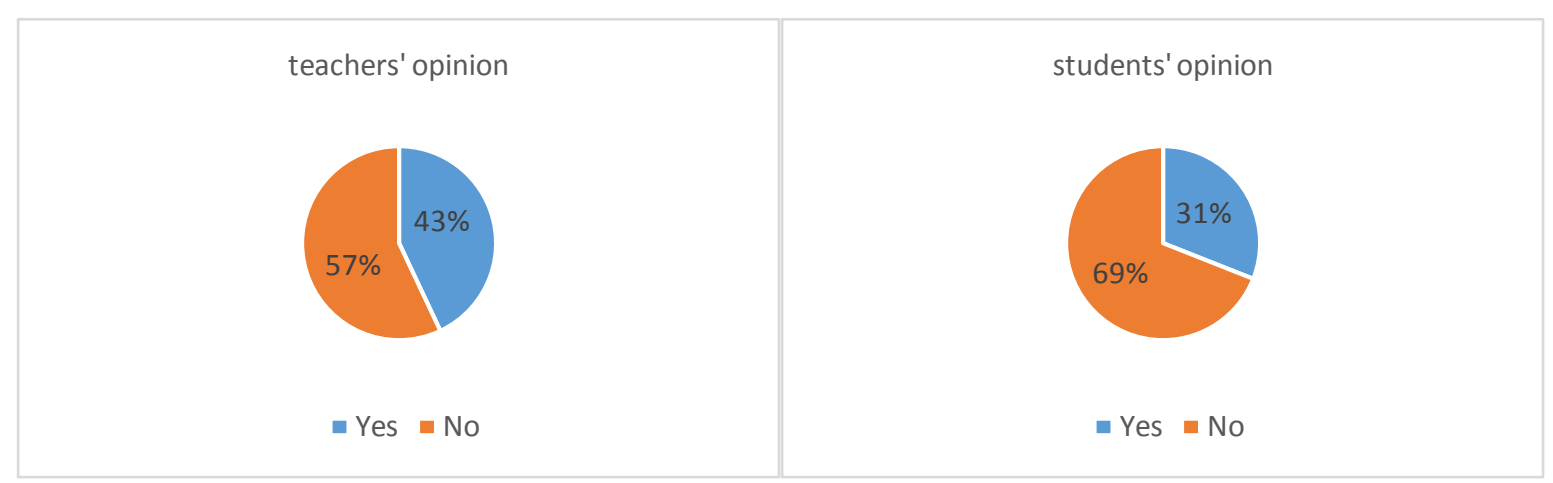

Figure 6. Finite The result of the sixth question in the questionnaire

Both teachers and students think that the intensive training courses in each semester cannot meet their practical needs and should be divided into several times according to the teaching curriculum. The scale should at the same time be enlarged.

It can be seen that there is a shortage of practice teaching bases. At present, there are few off-campus training bases in college business English practice teaching, which causes problems such as insufficient curriculum practice content and unreasonable off-campus training arrangement.

\section{The Improvement in the Construction of the Curriculum System of Business English Major.}

The aim of this paper is to find out problems and seek solutions. In order to perfect the teaching system for the purpose of business English major education in colleges and universities, based on the above investigations, the following strategies are put forward.

1. Optimize the construction principle of curriculum practical teaching system

Business English teaching in colleges should put the features and needs of the students in priority while at the same time make reasonable combination of theory and practice. On the premise of fact that the students' are individually respected,the details of practical courses should be carefully designed. The construction of college business English teaching system should follow the principle of student-orientation.[1] It should focus on the long-term development of students and attach equal importance to knowledge teaching and ability training. College business English should integrate subject teaching and skill training. [2]While improving students' ability of listening, speaking, reading and writing in business English, their ability to do and learn and their professional knowledge, skills, quality and moral character will also be improved. The focus should be put on the cultivation of students' English communication skills, business knowledge and business information processing skills.

Considering conditions of colleges and universities, student development characteristics and local factors such as the business English talent demand, colleges should make effective scientific improvement in teaching content design, practice arrange and internship. [3]

2. Optimize the implementation of practice teaching system construction

The construction of college business English teaching system needs to be completed through practice. On the premise of the above principles, the following aspects should be paid attention to the specific implementation process:

(1) Improve the curriculum of practice teaching system.

First of all, it is important to make clear about the target of talent training in Business English teaching. The construction of business English teaching course system should be enterprise-oriented. [4] Both meeting the needs of enterprises and the demand of the time and economic development are important goals.

Secondly, in view of the specific defects that exist in the practice teaching business English courses, such as unreasonable curriculum and improper teaching method, the colleges should focus on concrete optimization of practice teaching curriculum and teaching methods, etc,. [5]

Finally, after collecting a large number of valid data, on the basis of specific analysis, the colleges should ensure that the curriculum of business English major system is closely related to the market 
demand, the curriculum can be adjusted according to the requirements of enterprise personnel training direction and the value of talents cultivation can be achieved. [6]

(2) Improve the practice teaching base.

Practice teaching base, as a training platform for business English learning, not only help the practice training in business English teaching and learning, but also help the school win more students. Schools should invest more funds and increase and perfect the teaching infrastructures. At present, the ways of supplementing teaching base of the practice courses of business English include cooperating with related enterprises, expanding the present institutions and introducing advanced foreign teaching equipment and experts, etc.

(3) Arrange practice teaching scientifically and strengthen the application of skill training.

Application is one of the characteristics of college business English teaching. At present, the teaching of business English majors in colleges and universities in China mainly focuses on theoretical knowledge and less attention is paid to practice. Therefore, the construction and improvement of the curriculum system need to start from teachers and teaching activities, and properly strengthen the practical training of business English.

The applicability of skill training is fundamentally determined by the task of professional work. Only when theory and practical knowledge are truly combined with genuine working tasks can the practical skills training be realized. Therefore, it is necessary for teachers to receive regular training in enterprises. In this way the most authentic language materials are obtained. At the same time, teachers should consciously develop the cooperation with enterprises, establish development and service projects, and combine production, learning and research together. The teachers should transform from a pure teaching talent to a comprehensive dual teaching talent and ensure that their own theoretical practical teaching ability is strengthened.[7]

It is a long-term and systematic project. What needs to be emphasized is that the construction of business English curriculum is a dynamic process. It aims to satisfy the market needs. It should be adjusted according to market changes. The teachers should constantly learn and update knowledge and skills from market economic activities and maintain practicality.

\section{Conclusion}

This paper takes the current situation of business English teaching in colleges as the object of investigation and research, and analyzes the deficiencies according to the results. Based on the results, the paper puts forward relevant strategies of curriculum system construction, hoping to provide some references for the improvement of college business English teaching system and the long-term development of students.

\section{References}

[1] Weixin Huang, From Business English to English Business - a new model in the cultivation of compound talents, Exploration in International Trade, 2005.

[2] Jinyu Dong, Analysis of practical Business English Talent Teaching Mode Under Cross-Cultural Communication, Cross-Cultural Comminication, CS Canada, 10.3968/7308.

[3] Clarice S.C. Chan,Investigating a research-informed teaching idea: The use of transcripts of authentic workplace talk in the teaching of spoken business English, English for Specific Purposes, Elsevierjournal 10.1016/j.esp.2016.12.002.

[4] Wenzhong, Zhu, On differences between General English Teaching and Business English Teaching, English Language Teaching, 2009.

[5] Anne Kankaanranta, Journal of English as a Lingua Franca, De GRuyter, 10.1515-2015-0010

[6] Quentin Brand, Biz English for Busy People, first ed., Beijing, 2014.

[7] Information on http://www.weld.labs.gov.cnhttps://www.englishclub.com/business-english/ what.htm 